\title{
Pemodelan Faktor-faktor yang Mempengaruhi Angka Kematian Bayi dan Angka Kematian Ibu di Provinsi Jawa Timur Tahun 2017 dan Tahun 2018 Menggunakan Bivariate Gamma Regression
}

\author{
${ }^{1}$ Barep Adji Widhi P dan ${ }^{2}$ Purhadi \\ ${ }^{1,2}$ Departemen Statistika, FSAD, Institut Teknologi Sepuluh Nopember (ITS) \\ Jl. Arief Rahman Hakim, Surabaya 60111 Indonesia \\ e-mail: 'barepadjiwidhi@gmail.com, ${ }^{2}$ purhadi@ statistika.its.ac.id
}

\begin{abstract}
Abstrak-Kematian Bayi dan Ibu merupakan salah satu indikator kesejahteraan masyarakat yang menjadi tujuan utama dalam Sustainable Development Goals (SDGs). Angka Kematian Bayi dan Angka Kematian Ibu di Jawa Timur dikhawatirkan dapat meningkat melewati target yang ditentukan SDGs. Salah satu upaya untuk menekan angka kematian bayi maupun ibu adalah dengan terus menelaah faktor-faktor penyebabnya. Permasalahan ini dapat diselesaikan dengan metode Bivariat Gamma Regression untuk mengetahui faktor yang mempengaruhi Angka Kematian Bayi dan Angka Kematian Ibu. Data yang digunakan berasal dari Dinas Kesehatan Jawa Timur berupa publikasi Profil Kesehatan Provinsi Jawa Timur tahun 2017 dan 2018. Variabel yang diduga mempengaruhi Angka Kematian Bayi dan Angka Kematian Ibu adalah persentase persalinan oleh tenaga kesehatan, persentase komplikasi kebidanan yang ditangani, persentase bayi lahir berat badan rendah, persentase penduduk miskin, dan persentase perempuan kawin dibawah 17 tahun. Pada pengujian kesamaan model BGR tahun 2017 dan tahun 2018 menghasilkan model yang berbeda.
\end{abstract}

Kata Kunci- Angka Kematian Bayi, Angka Kematian Ibu, Bivariare Gamma Regression, Jawa Timur

\section{PENDAHULUAN}

A ngka kematian bayi dan angka kematian ibu merupakan salah satu tolok ukur penilaian terhadap kinerja pemerintah daerah khususnya departemen kesehatan dalam usaha memperbaiki derajat kesehatan masyarakat. Sampai saat ini angka kematian bayi dan angka kematian ibu yang ada di Indonesia masih cukup tinggi. Sehingga masalah kesehatan bayi dan ibu masih menjadi masalah yang perlu diperhatikan di Indonesia. Salah satu tujuan pembangunan Sustanaible Development Goals (SDGs) yaitu menurunkan angka kematian Bayi pada tahun 2030 menjadi 23 per 1000 kelahiran hidup.

Pada tahun 2017 Angka Kematian Bayi di Jawa Timur sebesar 23,10 per 1.000 kelahiran hidup dan Angka Kemaian Anak sebesar 2,55 per 1000 kelahiran hidup. Pada tahun 2018 Angka Kematian Bayi di Jawa Timur menurun menjadi sebesar 20,44 per 1000 kelahiran hidup dan Angka Kematian Ibu sebesar 91,45 per 100.000 kelahiran hidup. Keadaan Angka Kematian Bayi (AKB) dan Angka Kematian Ibu (AKB) yang diperoleh dari laporan rutin relatif sangat kecil. Namun bila dihitung angka kematian absolut masih tinggi yaitu sebanyak 4.016 Bayi meninggal pertahun [1].

Pada tahun 2018 Angka Kematian Bayi tersbesar terletak di Kab. Bondowoso mencapai 16,99 per 1000 kelahiran hidup atau 172 kasus bayi meninggal, sedangkan Angka Kematian Bayi terkecil terletak di Kab. Malang sebesar 2,19 per 1000 kelahiran hidup atau sebesar 84 kasus bayi meninggal pertahun. Angka Kematian Ibu terbesar terjadi di Kota Pasuruan sebesar 301,75 per 100.000 kelahiran hidup, sedangkan Angka Kematian Ibu terendah terjadi di Kab. Malang sebesar 46,48 per 100.000 kelahiran hidup. Jumlah kematian bayi dan jumlah kematian ibu merupakan dua hal yang saling berkaitan karena selama masa setelah melahirkan, gizi yang diperoleh bayi akan membantu melawan penyakit dan mengurangi reisko kematian sehingga kondisi bayi selama masa kelahiran akan berpengaruh pada anak yang akan tumbuh besar nantinya.

Oleh karena itu perlu dilakukan suatu penelitian mengenai faktor-faktor yang mempengaruhi angka kematian bayi dan angka kematian ibu secara bersamaan sebagai rekomendasi kepada pemerintah untuk menekan angka kematian bayi dan angka kematian ibu di Jawa Timur. Pada penelitian ini akan digunakan pendekatan Regresi Gamma Bivariat karena dari dua variabel respon tersebut memiliki hubungan yang signifikan sehingga dilakukan pemodelan dari angka kematian bayi dan angka kematian ibu di Provinsi Jawa Timur tahun 2018, selain itu dilakukan perbandingan antara model yang diperoleh pada tahun 2018 dan pada tahun 2017. Perbandingan model antara tahun 2017 dan tahun 2018 dilakukan untuk melihat faktor-faktor yang mempengaruhi angka kematian bayi maupun kematian ibu pada tahun 2017 memiliki kesamaan dengan tahun 2018 dan untuk mengetahui karakteristik dari kedua model sama atau tidak. Penelitian ini diharapkan memberikan kontribusi yang dapat dilakukan pemerintah sebagai upaya penurunan angka kematian bayi dan anak atau perencanaan program preventif kematian bayi dan kematian anak di provinsi Jawa Timur berdasarkan faktorfaktor yang berpengaruh

\section{TINJAUAN PUSTAKA}

\section{A. Statistika Deskriptif}

Statistika deskriptif merupakan metode yang berkaitan dengan pengumpulan dan penyajian data sehingga memberikan informasi hanya mengenai data dan tidak menarik kesimpulan [2]. Pada penelitian ini akan digunakan statistika deskriptif berupa nilai minimum, nilai maksimum, dan rata-rata. 


$$
\begin{aligned}
\bar{x} & =\frac{\sum_{i=1}^{n} X_{i}}{n}, i=1,2, \ldots, n \\
s^{2} & =\frac{\sum_{i=1}^{n}(x-\bar{x})^{2}}{n-1}
\end{aligned}
$$

B. Distribusi Gamma Univariate

Distribusi gamma merupakan salah satu dari distribusi probabilitas kontinyu. Distribusi gamma berasal dari fungsi gamma yang memiliki fungsi kepadatan peluang (fkp) sama dengan satu. Distribusi gamma menghasilkan kurva dengan skewness. Fungsi kepadatan peluang dari distribusi gamma tiga parameter adalah sebagai berikut [3].

$f(y \mid \alpha, \theta, \lambda)=\left\{\begin{array}{c}\frac{1}{\theta^{\alpha} \Gamma(\alpha)}(y-\lambda)^{\alpha-1} e^{-(y-\lambda) / \theta}, \alpha>0, \theta>0, \lambda<y<\infty \\ 0, \text { untuk y yang lainnya }\end{array}\right.$

\section{Distribusi Gamma Bivariate}

Distribusi Bivariate Gamma memiliki dua variabel random yang saling berkorelasi. Salah satu bentuk pdf distribusi bivariate gamma dapat diperoleh dengan transformasi berdasarkan karakteristik dari distribusi gamma dan distribusi beta [4].

$$
f\left(y_{1}, y_{2}\right)=\left\{\begin{array}{c}
C\left(y_{1} \cdot y_{2}\right)^{\tau-1}\left(\frac{y_{1}}{\mu_{1}}+\frac{y_{2}}{\mu_{2}}\right)^{\alpha-2 \tau} \Gamma\left(2 \tau-\alpha, \frac{y_{1}}{\mu_{1}}+\frac{y_{2}}{\mu_{2}}\right) \\
0, \text { untuk } \mathrm{y}_{1}, \mathrm{y}_{2} \text { yang lainnya }
\end{array}\right.
$$

dimana $\quad C=\left(\left(\mu_{1} \mu_{2}\right)^{\tau} \Gamma(\tau) \Gamma(\alpha)\right)^{-1} \quad$ dan $y_{1}>0, y_{2}>$ $0, \alpha>0, \tau>0$.

\section{Uji Distribusi Gamma}

Pengujian untuk mengetahui sebaran data variabel respon ini dilakukan dengan uji Anderson-Darling (AD). Uji ini merupakan modifikasi dari uji Kolmogorov-Smirnov (KS) yang digunakan untuk menguji apakah sampel berasal dari populasi dengan distribusi tertentu. Nilai kritis dalam uji KS tidak tergantung pada distribusi tertentu yang sedang diuji, sedangkan AD memanfaatkan distribusi tertentu dalam menghitung titik kritis [5]. Hipotesis yang digunakan sebagai berikut:

dengan statistik uji:

$$
\begin{aligned}
& \mathrm{H}_{0}: F_{y}=F_{y}^{0} \\
& \mathrm{H}_{1}: F_{y} \neq F_{y}^{0}
\end{aligned}
$$

$$
A^{2}=-n-\frac{1}{n} \sum_{i=1}^{n}(2 i-1)\left(\ln F_{y_{i}}^{0}+\ln \left(1-F_{\left(y_{n+1-i}\right)}^{0}\right)\right.
$$

$F_{y_{i}}^{0}$ merupakan fungsi distribusi komulatif. Keputusan tolak $\mathrm{H}_{0}$ diambil jika $A^{2}>A_{\alpha}^{2}$. Pengujian distribusi dilakukan secara univariate, model bivariate gamma terbentuk dari variabel respon yang saling berkorelasi dimana masingmasing variabel respon berdistribusi gamma [6].

\section{E. Univariate Gamma Regression}

Regresi gamma univariate merupakan bentuk regresi yang dapat menggambarkan hubungan satu variabel respon (Y) dengan variabel prediktor (X), di mana distribusi dari variabel respon harus mengikuti distribusi gamma. Model regresi gamma univariate adalah sebagai berikut:

$$
\mu_{i}=E\left(Y_{i}\right)=\exp \left(\beta_{0}+\beta_{1} x_{i 1}+\cdots+\beta_{k} x_{i k}\right)
$$

Fungsi kepadatan peluang dari model regresi gamma univariate adalah:

$$
f\left(y_{i} \mid \alpha, \gamma\right)=\left\{\begin{array}{cc}
\frac{\left(\frac{\alpha}{\exp \left(x_{i}^{T} \beta\right)}\right)^{\alpha} y_{i}^{\alpha-1} e^{-\left(\frac{\alpha}{\exp \left(x_{i}^{T} \beta\right)}\right) y_{i}}}{\Gamma(\alpha)}, \mathrm{y}_{i}>0, \alpha>0, \gamma>0 \\
0, \text { untuk y yang lainnya }
\end{array}\right.
$$

\section{F. Penaksiran Parameter Univariate Gamma Regression}

Penaksiran parameter dilakukan dengan metode maximum likelihood estimator (MLE). Metode MLE bertujuan untuk memaksimumkan nilai fungsi lnlikelihood [7].

$$
\begin{gathered}
\ln L(\alpha, \beta, \mathrm{i}=1,2, \cdots, \mathrm{n})=\ln \left(\prod_{\mathrm{i}=1}^{\mathrm{n}}\left(\frac{\left(\frac{\alpha}{\exp \left(\mathbf{x}_{\mathrm{T}}^{T} \boldsymbol{\beta}\right)}\right)^{\alpha}}{\Gamma(\alpha)} y_{\mathrm{i}}^{\alpha-1} \exp \left(-\frac{\mathrm{y}_{\mathrm{i}} \alpha}{\exp \left(\mathbf{x}_{\mathrm{i}}^{\mathrm{T}} \boldsymbol{\beta}\right)}\right)\right)\right) \\
=-n \ln \Gamma(\alpha)-\alpha \sum_{i=1}^{n}\left(\boldsymbol{x}_{i}^{T} \boldsymbol{\beta}\right)+\alpha(n \ln \alpha)+ \\
(\alpha-1) \sum_{i=1}^{n} \ln y_{i}-\sum_{i=1}^{n}\left(\frac{y_{i} \alpha}{\exp \left(\boldsymbol{x}_{i}^{T} \boldsymbol{\beta}\right)}\right)
\end{gathered}
$$

Turunan parsial fungsi ln $L(\alpha, \beta)$ terhadap parameter $\boldsymbol{\beta}$ :

$$
\frac{\partial \ln \mathrm{L}(\mathrm{a}, \boldsymbol{\beta})}{\partial \boldsymbol{\beta}}=-\mathrm{a} \sum_{\mathrm{i}=1}^{\mathrm{n}} \mathrm{x}_{\mathrm{i}}^{\mathrm{T}}+\mathrm{a} \sum_{\mathrm{i}=1}^{\mathrm{n}} \mathrm{x}_{\mathrm{i}}^{\mathrm{T}} \mathrm{y}_{\mathrm{i}}\left(\exp \left(\mathbf{x}_{\mathrm{i}}^{\mathrm{T}} \boldsymbol{\beta}\right)\right)^{-1}
$$

Turunan parsial fungsi $\ln L(\alpha, \boldsymbol{\beta})$ terhadap parameter $\alpha$ :

$$
\begin{aligned}
& \frac{\partial \ln L(\alpha, \boldsymbol{\beta})}{\partial \alpha}=-n \psi(\alpha)-\sum_{i=1}^{n}\left(\boldsymbol{x}_{i}^{T} \boldsymbol{\beta}\right)+n(\ln \alpha+1) \\
& +\sum_{i=1}^{n} \ln y_{i}-\sum_{i=1}^{n}\left(\frac{y_{i}}{\exp \left(\boldsymbol{x}_{i}^{T} \boldsymbol{\beta}\right)}\right)
\end{aligned}
$$

Persamaan diatas menghasilkan penyelesaian yang tidak closed-form, sehingga untuk penyelesaiannya digunakan pendekatan numerik yaitu dengan algoritma BHHH (BerndtHall-Hall-Hausman).

\section{G. Pengujian Parameter Univariate Gamma Regression}

Pengujian serentak parameter model regresi gamma univariate dilakukan menggunakan metode Maximum Likelihood Ratio Test (MLRT), dengan hipotesis sebagai berikut:

$H_{0}: \beta_{1}=\beta_{2}=\cdots=\beta_{k}=0$

$H_{1}$ : paling sedikit ada satu $\beta_{l} \neq 0 ; l=1,2, \cdots, k$

Statistik uji yang digunakan adalah:

$$
\mathrm{G}^{2}=-2 \ln \Lambda=-2 \ln \left(\frac{\mathrm{L}(\widehat{\omega})}{\mathrm{L}(\widehat{\Omega})}\right)=-2(\ln L(\widehat{\omega})-\ln \mathrm{L}(\widehat{\Omega}))
$$

$\mathrm{H}_{0}$ ditolak jika $G^{2}>\chi_{\alpha, k}^{2}$. Apabila keputusan pengujian secara serentak adalah tolak $H_{0}$, maka pengujian dilanjutkan dengan uji parsial. Hipotesis yang digunakan dalam uji parsial ini adalah:

$$
\begin{gathered}
H_{0}: \beta_{l}=0 \\
H_{1}: \beta_{l} \neq 0 \quad ; l=1,2, \cdots, k
\end{gathered}
$$

Statistik uji yang digunakan adalah:

$$
Z=\frac{\widehat{\beta}_{l}}{\operatorname{se}\left(\widehat{\beta}_{l}\right)} \text {, di mana } s e\left(\hat{\beta}_{l}\right)=\sqrt{\widehat{\operatorname{var}\left(\hat{\beta}_{l}\right)}}
$$

Tolak $\mathrm{H}_{0}$ jika $|Z|>Z_{\alpha / 2}$.

\section{H. Bivariate Gamma Regression}

Bivariate Gamma Regression (BGR) adalah bentuk regresi yang menggambarkan hubungan antara dua variabel respon $\left(\mathrm{Y}_{1}\right.$ dan $\left.\mathrm{Y}_{2}\right)$ yang masing-masing berdistribusi gamma dengan sekumpulan variabel prediktor $(\mathrm{X})$. Model regresi gamma bivariate adalah sebagai berikut:

$$
\begin{aligned}
& \mu_{1 i}=E\left(Y_{1}\right)=\exp \left(\boldsymbol{x}_{i}^{T} \boldsymbol{\beta}_{1}\right) \\
& \mu_{2 i}=E\left(Y_{2}\right)=\exp \left(\boldsymbol{x}_{i}^{T} \boldsymbol{\beta}_{2}\right)
\end{aligned}
$$


Bentuk pdf model regresi gamma bivariate adalah sebagai berikut:

$$
\begin{aligned}
& \left(Y_{1 i}, Y_{2 i}\right) \sim \text { Bivariate } \operatorname{Gamma}\left(\alpha, \tau, \beta_{1}, \beta_{2}\right) \\
& f\left(y_{1 i}, y_{2 i}\right)=\left\{\begin{array}{c}
\mathrm{C}_{\mathrm{i}}\left(\mathrm{y}_{1 \mathrm{i}} \cdot \mathrm{y}_{2 \mathrm{i}}\right)^{\tau-1}\left(\frac{\mathrm{y}_{1 \mathrm{i}}}{\exp \left(\mathbf{x}_{\mathrm{i}}^{\mathrm{T}} \boldsymbol{\beta}_{1}\right)}+\frac{\mathrm{y}_{2 \mathrm{i}}}{\exp \left(\mathbf{x}_{\mathrm{i}}^{\mathrm{T}} \boldsymbol{\beta}_{2}\right)}\right)^{\alpha-2 \tau} \mathrm{A}_{\mathrm{i}} \\
0, \text { untuk } \mathrm{y}_{1 \mathrm{i}}, \mathrm{y}_{2 \mathrm{i}} \text { yang lainnya }
\end{array}\right.
\end{aligned}
$$

$\operatorname{dimana} y_{1 i}>0, y_{2 i}>0, \alpha>0, \tau>0 ; i=1,2, \cdots, n$

$$
\begin{aligned}
C_{i} & =\left(\left(\exp \left(\boldsymbol{x}_{i}^{T} \boldsymbol{\beta}_{1}\right) \exp \left(\boldsymbol{x}_{i}^{T} \boldsymbol{\beta}_{2}\right)\right)^{\tau} \Gamma(\tau) \Gamma(\alpha)\right)^{-1} \\
A_{i} & =\Gamma\left(2 \tau-\alpha, \frac{y_{1 i}}{\exp \left(\boldsymbol{x}_{i}^{T} \boldsymbol{\beta}_{1}\right)}+\frac{y_{2 i}}{\exp \left(\boldsymbol{x}_{i}^{T} \boldsymbol{\beta}_{2}\right)}\right)
\end{aligned}
$$

\section{Penaksiran Parameter Bivariate Gamma Regression}

Penaksiran parameter Bivariate Gamma Regression dilakukan dengan metode Maximum Llikelihood Estimator (MLE). fungsi lnlikelihood bivariate gamma adalah sebagai berikut [8]:

$$
\begin{gathered}
\ln L\left(\alpha, \tau, \beta_{1}, \beta_{2}, i=1,2, \cdots, n\right) \\
=\sum_{\mathrm{i}=1}^{\mathrm{n}} \ln \left(\mathrm{C}_{\mathrm{i}}\left(\mathrm{y}_{1 \mathrm{i}} \cdot \mathrm{y}_{2 \mathrm{i}}\right)^{\mathrm{T}-1}\left(\frac{\mathrm{y}_{1 \mathrm{i}}}{\exp \left(\mathbf{x}_{\mathrm{i}}^{\mathrm{T}} \boldsymbol{\beta}_{1}\right)}+\frac{\mathrm{y}_{2 \mathrm{i}}}{\exp \left(\mathbf{x}_{\mathrm{i}}^{\mathrm{T}} \boldsymbol{\beta}_{2}\right)}\right)^{\mathrm{a}-2 \mathrm{~T}} \mathrm{~A}_{\mathrm{i}}\right)
\end{gathered}
$$

Penaksiran parameter pada regresi gamma diperoleh dengan memaksimumkan fungsi $L\left(\alpha, \tau, \beta_{1}, \beta_{2}\right)$ yaitu dengan cara mencari turunan pertama persamaan untuk parameter $\alpha, \tau, \beta_{1}, \beta_{2}$ disama dengankan nol.

Turunan pertama terhadap parameter $\alpha$ :

$\frac{\partial \ln L\left(\alpha, \tau, \beta_{1}, \beta_{2}\right)}{\partial \alpha}=-n \psi(\alpha)+\sum_{i=1}^{n} \ln \left(\frac{y_{1 i}}{\exp \left(\mathbf{x}_{\mathrm{i}}^{\mathrm{T}} \boldsymbol{\beta}_{1}\right)}+\frac{\mathrm{y}_{2 \mathrm{i}}}{\exp \left(\mathbf{x}_{\mathrm{i}}^{\mathrm{T}} \boldsymbol{\beta}_{2}\right)}\right)+\frac{\partial\left(\sum_{\mathrm{i}=1}^{\mathrm{n}} \ln \mathrm{A}_{\mathrm{i}}\right)}{\partial \alpha}$

Turunan pertama terhadap parameter $\tau$ :

$$
\begin{gathered}
\frac{\partial \ln L\left(\alpha, \tau, \boldsymbol{\beta}_{1}, \boldsymbol{\beta}_{2}\right)}{\partial \tau}=-\sum_{i=1}^{n}\left(\boldsymbol{x}_{i}^{T} \boldsymbol{\beta}_{1}+\boldsymbol{x}_{i}^{T} \boldsymbol{\beta}_{2}\right)-n \psi(\tau)+\sum_{i=1}^{n} \ln y_{1 i} y_{2 i} \\
-2 \sum_{i=1}^{n} \ln \left(\frac{y_{1 i}}{\exp \left(\boldsymbol{x}_{i}^{T} \boldsymbol{\beta}_{1}\right)}+\frac{y_{2 i}}{\exp \left(\boldsymbol{x}_{i}^{T} \boldsymbol{\beta}_{2}\right)}\right)+\frac{\partial\left(\sum_{i=1}^{n} \ln A_{i}\right)}{\partial \tau}
\end{gathered}
$$

Turunan pertama terhadap parameter $\boldsymbol{\beta}_{1}$ :

$$
\begin{gathered}
\frac{\partial \ln L\left(\alpha, \tau, \boldsymbol{\beta}_{1}, \boldsymbol{\beta}_{2}\right)}{\partial \boldsymbol{\beta}_{1}}=-\tau \sum_{i=1}^{n} \boldsymbol{x}_{i}^{T}+(\alpha-2 \tau) \\
\left(\sum_{i=1}^{n}-\frac{y_{1 i} \boldsymbol{x}_{i}^{T}}{\exp \left(\boldsymbol{x}_{i}^{T} \boldsymbol{\beta}_{1}\right)\left(\frac{y_{1 i}}{\exp \left(\boldsymbol{x}_{i}^{T} \boldsymbol{\beta}_{1}\right)}+\frac{y_{2 i}}{\exp \left(\boldsymbol{x}_{i}^{T} \boldsymbol{\beta}_{2}\right)}\right)}\right)+ \\
\sum_{i=1}^{n} \frac{\ln y_{1 i} x_{i}^{T}\left(\frac{y_{1 i}}{\exp \left(\boldsymbol{x}_{i}^{T} \boldsymbol{\beta}_{1}\right)}+\frac{y_{2 i}}{\exp \left(\boldsymbol{x}_{i}^{T} \boldsymbol{\beta}_{2}\right)}\right)^{2 \tau-\alpha-1} \exp \left(-\frac{y_{1 i}}{\exp \left(\boldsymbol{x}_{i}^{T} \boldsymbol{\beta}_{1}\right)}-\frac{y_{2 i}}{\exp \left(\boldsymbol{x}_{i}^{T} \boldsymbol{\beta}_{2}\right)}\right)}{\exp \left(\boldsymbol{x}_{i}^{T} \boldsymbol{\beta}_{1}\right)}
\end{gathered}
$$

Turunan pertama terhadap parameter $\boldsymbol{\beta}_{2}$ :

$\frac{\partial \ln L\left(\alpha, \tau, \beta_{1}, \beta_{2}\right)}{\partial \boldsymbol{\beta}_{2}}=-\tau \sum_{i=1}^{n} \boldsymbol{x}_{i}^{T}+(\alpha-2 \tau)$

$$
\begin{gathered}
\left(\sum_{i=1}^{n}-\frac{y_{2 i} \boldsymbol{x}_{i}^{T}}{\exp \left(\boldsymbol{x}_{i}^{T} \boldsymbol{\beta}_{2}\right)\left(\frac{y_{1 i}}{\exp \left(\boldsymbol{x}_{i}^{T} \boldsymbol{\beta}_{1}\right)}+\frac{y_{2 i}}{\exp \left(\boldsymbol{x}_{i}{ }^{T} \boldsymbol{\beta}_{2}\right)}\right)}\right)+ \\
\sum_{i=1}^{n} \frac{\ln y_{2 i} x_{i}^{T}\left(\frac{y_{1 i}}{\exp \left(\boldsymbol{x}_{i}{ }^{T} \boldsymbol{\beta}_{1}\right)}+\frac{y_{2 i}}{\exp \left(\boldsymbol{x}_{i}{ }^{T} \boldsymbol{\beta}_{2}\right)}\right)^{2 \tau-\alpha-1} \exp \left(-\frac{y_{1 i}}{\exp \left(\boldsymbol{x}_{i}{ }^{T} \boldsymbol{\beta}_{1}\right)}-\frac{y_{2 i}}{\exp \left(\boldsymbol{x}_{i}^{T} \boldsymbol{\beta}_{2}\right)}\right)}{\exp \left(\boldsymbol{x}_{i}^{T} \boldsymbol{\beta}_{2}\right)}
\end{gathered}
$$

Hasil turunan pertama terhadap parameter $\alpha, \tau, \beta_{1}, \beta_{2}$ di atas menghasilkan penyelesaian yang tidak closed-form, sehingga dilakukan optimasi numerik dengan algoritma BHHH (Berndt-Hall-Hall-Hausman).

\section{J. Pengujian Parameter Bivariate Gamma Regression}

Pengujian serentak parameter model regresi gamma univariate dilakukan menggunakan metode Maximum Likelihood Ratio Test (MLRT), dengan hipotesis sebagai beriku [8]:

$\mathrm{H}_{0}: \beta_{11}=\beta_{12}=\ldots=\beta_{1 k}=\beta_{21}=\beta_{22}=\ldots=\beta_{2 k}=0$

$\mathrm{H}_{1}$ : paling sedikit ada satu $\beta_{j l} \neq 0 ; l=1,2, \ldots, k ; j=1,2$

dimana $\mathrm{k}$ adalah banyaknya variabel prediktor.

Statistik uji yang digunakan adalah:

$$
\mathrm{G}^{2}=-2 \ln \Lambda=-2 \ln \left(\frac{\mathrm{L}(\widehat{\omega})}{\mathrm{L}(\widehat{\Omega})}\right)=-2(\ln \mathrm{L}(\widehat{\omega})-\ln \mathrm{L}(\widehat{\Omega}))
$$

$\mathrm{H}_{0}$ ditolak jika $G^{2}>\chi_{\alpha, k}^{2}$. Apabila keputusan pengujian secara serentak adalah tolak $H_{0}$, maka pengujian dilanjutkan dengan uji parsial. Hipotesis yang digunakan dalam uji parsial ini adalah:

$$
\begin{gathered}
H_{0}: \beta_{j l}=0 \\
H_{1}: \beta_{j l} \neq 0 \quad ; l=1,2, \cdots, k ; j=1,2
\end{gathered}
$$

Statistik uji yang digunakan adalah:

$$
Z=\frac{\widehat{\beta}_{j l}}{\operatorname{se}\left(\widehat{\beta}_{j l}\right)} \operatorname{dimana} \operatorname{se}\left(\hat{\beta}_{j l}\right)=\sqrt{\widehat{\operatorname{var}\left(\hat{\beta}_{j l}\right)}}
$$

$\mathrm{H}_{0}$ ditolak jika $|Z|>Z_{\alpha / 2}$.

\section{K. Pengujian Kesamaan Kedua Model}

Pengujian kesamaan model ini bertujuan untuk menguji kesamaan faktor-faktor yang mempengaruhi kedua model. Pengujian kesamaan model ini dilakukan dengan membandingkan nilai likelihood model BGR kesatu dan model BGR yang kedua.

Model BGR ke-1 adalah sebagai berikut :

$$
\begin{aligned}
& \mu_{11}=E\left(Y_{11}\right)=\exp \left(\mathbf{x}^{T} \boldsymbol{\beta}_{11}\right) \\
& \mu_{21}=E\left(Y_{21}\right)=\exp \left(\mathbf{x}^{T} \boldsymbol{\beta}_{21}\right)
\end{aligned}
$$

Model BGR ke-2 adalah sebagai berikut :

$$
\begin{aligned}
& \mu_{12}=E\left(Y_{12}\right)=\exp \left(\mathbf{x}^{T} \boldsymbol{\beta}_{12}\right) \\
& \mu_{22}=E\left(Y_{22}\right)=\exp \left(\mathbf{x}^{T} \boldsymbol{\beta}_{22}\right)
\end{aligned}
$$

Hipotesis yang digunakan adalah sebagai berikut:

$$
\begin{aligned}
& H_{0}: \beta_{j 1}=\beta_{j 2}, j=1,2 \\
& H_{0}: \beta_{j 1} \neq \beta_{j 2}, j=1,2
\end{aligned}
$$

Statistik uji yang digunakan adalah merupakan perbandingan nilai likelihood dari model BGR ke-1 dan model BGR ke-2 :

$$
F_{\text {hitung }}=\frac{G_{1}^{2} / d f_{1}}{G_{2}^{2} / d f_{2}}
$$

$G_{1}^{2}$ merupakan devians dari model BGR ke-1 dengan derajat bebas $\mathrm{df}_{1}$ dan $G_{2}^{2}$ merupakan devians dari model BGR ke-2 dengan derajat bebas $\mathrm{df}_{2}$. Kriteria pengambilan keputusan adalah tolak $\mathrm{H}_{0}$ apabila $F_{\text {hitung }}>F_{\left(\alpha, d f_{1}, d f_{2}\right)}$ [8].

\section{Koefisien Korelasi}

Koefisien korelasi merupakan suatu indikator untuk mengetahui hubungan linier antara dua variabel. Nilai koefisien korelasi berada pada rentang $-1 \leq r_{y_{1}, y_{2}} \leq 1$. Jika nilai korelasi mendekati angka 1 maka kedua variabel itu memiliki hubungan secara linier sedangkan jika nilai koefisien korelasi bernilai 0, maka dapat dikatakan bahwa kedua variabel tersebut tidak memiliki hubungan secara linier. Koefisien korelasi didefinisikan sebagai berikut [9]: 


$$
r_{y_{1}, y_{2}}=\frac{n \sum_{i=1}^{n} y_{1 i} y_{2 i}-\left(\sum_{i=1}^{n} y_{1 i} \sum_{i=1}^{n} y_{2 i}\right)}{\sqrt{\left[n \sum_{i=1}^{n} y_{1 i}^{2}-\left(\sum_{i=1}^{n} y_{1 i}\right)^{2}\right]\left[n \sum_{i=1}^{n} y_{2 i}^{2}-\left(\sum_{i=1}^{n} y_{2 i}\right)^{2}\right]}}
$$

\section{Multikolinieritas}

Multikolinieritas adalah suatu kondisi dimana terjadi korelasi tinggi antar variabel prediktornya. Multikolinieritas mengakibatkan penaksir parameter yang diperoleh menjadi tidak akurat. Salah satu cara mengidentifikasi adanya multikolinearitas yaitu dengan Variance Inflation Factors (VIF) yang dinyatakan sebagai berikut [9]:

$$
V I F_{l}=\frac{1}{\left(1-R_{l}^{2}\right)} \quad ; \quad l=1,2, \ldots, k
$$

\section{N. Angka Kematian Bayi}

Kematian bayi adalah kematian yang terjadi sesaat setelah bayi dilahirkan sampai bayi belum berusia kurang dari satu tahun. AKB merupakan kematian per 1000 kelahiran hidup yang terjadi pada bayi dengan usia kurang dari satu tahun atau disebut juga dengan probabilitas bayi meninggal sebelum mencapai umur satu tahun dalam 1000 kelahiran hidup. Menurut BPS, untuk menghitung angka kematian bayi (AKB) adalah sebagai berikut:

$$
A K B=\frac{\sum K_{0-<1 \text { th }}}{\sum \text { Kelahiran Hidup }} \times 1000
$$

\section{O. Angka Kematian Ibu}

Kematian ibu menurut definisi WHO adalah kematian selama kehamilan atau dalam periode 42 hari setelah berakhirnya kehamilan, yang disebabkan oleh kehamilan atau penanganannya, tetapi bukan disebabkan oleh kecelakaan atau cedera. AKI merupakan banyaknya kematian perempuan pada saat hamil atau selama 42 hari sejak terminasi kehamilan tanpa memandang lama dan tempat persalinan, yang disebabkan karena kehamilannya atau pengelolaannya, dan bukan karena sebab-sebab lain, per 100.000 kelahiran hidup. Menurut BPS, untuk menghitung angka kematian ibu (AKI) adalah sebagai berikut:

$$
A K I=\frac{D_{\text {hamil }}}{\sum \text { Kelahiran Hidup }} \times 100.000
$$

P. Faktor-Faktor yang Diduga Berpengaruhi pada Angka Kematian Bayi dan Angka Kematian Ibu

Faktor - faktor yang diduga mempengaruhi AKB dan AKI di Provinsi Jawa Timur adalah persentase persalinan oleh tenaga kesehatan, persentase komplikasi kebidanan yang ditangani, persentase bayi lahir berat badan rendah, presentase penduduk miskin, dan persentase perempuan kawin dibawah 17 tahun.

Kerangka konsep kematian bayi dan ibu oleh Mosley dan Chen dan kematian ibu oleh McCarthy dan Maine. Dalam penelitian ini dilakukan beberapa modifikasi terhadap model McCarthy dan Maine (1992) berikut ini.

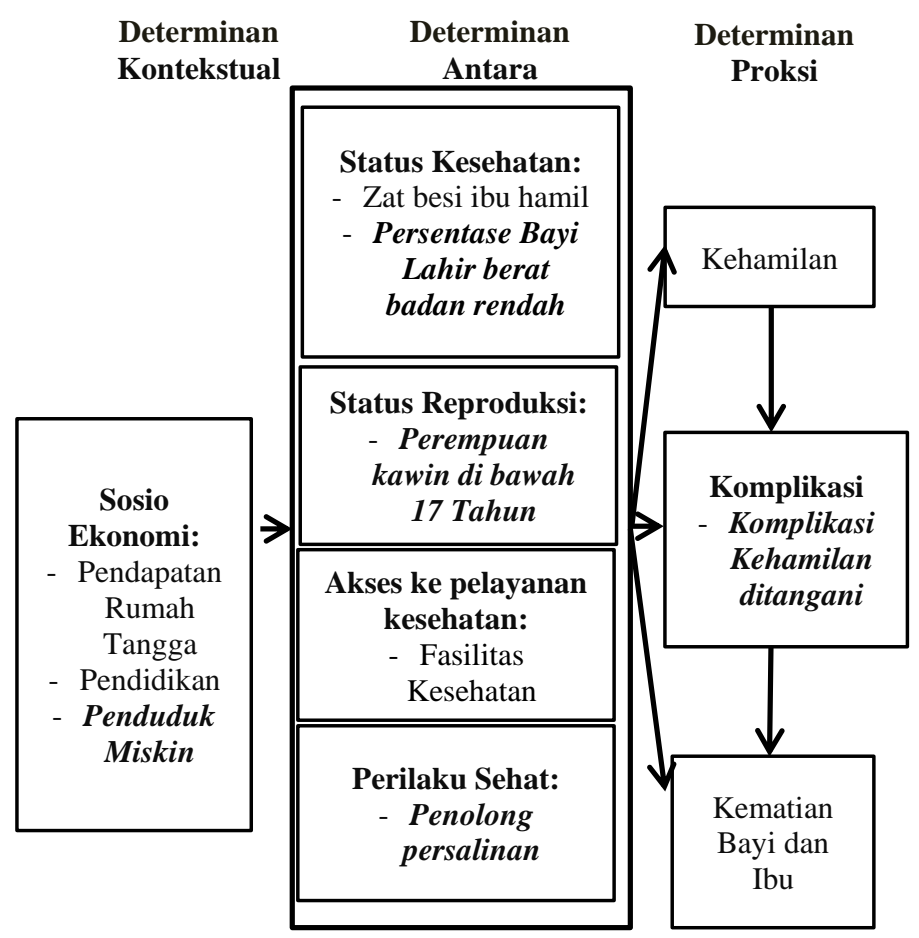

Gambar 1. Modifikasi Model Konseptual McCarthy dan Maine (1992) pada Faktor - Faktor yang mempengaruhi Angka Kematian Bayi dan Angka Kematian Ibu di Jawa Timur

\section{A. Sumber Data}

\section{METODOLOGI PENELITIAN}

Data yang digunakan dalam penelitian adalah data sekunder yang diperoleh dari Publikasi Profil Kesehatan Provinsi Jawa Timur tahun 2017 dan tahun 2018 dari Dinas Kesehatan (Dinkes) Jawa Timur dan Publikasi Indikator Kesejahteraan Rakyat Provinsi Timur tahun 2017 dan tahun 2018. Unit pengamatan sebanyak 34 Unit pengamatan yang terdiri atas 29 Kabupaten dan 5 Kota di Provinsi Jawa Timur. Unit pengamatan yang digunakan yaitu Kab./Kota yang tidak memiliki nilai nol pada Angka Kematian Bayi atau Angka Kematian Ibu.

\section{B. Variabel Penelitian}

Pada penelitian ini Variabel penelitian yang digunakan terdiri atas dua variabel respon (Y) dan lima variabel prediktor (X) ditampilkan pada Tabel 1.

TABEL 1.

VARIABEL PENELITIAN

\begin{tabular}{ccc}
\hline Variabel & Keterangan & $\begin{array}{c}\text { Sumber } \\
\text { Data }\end{array}$ \\
\hline $\boldsymbol{Y}_{\mathbf{1}}$ & Angka Kematian Bayi & Dinkes \\
$\boldsymbol{Y}_{\mathbf{2}}$ & Angka Kematian Ibu & Dinkes \\
$\boldsymbol{X}_{\mathbf{1}}$ & Persentase Persalinan oleh tenaga & kesehatan \\
& Persentase Komplikasi Kebidanan yang & Dinkes \\
$\boldsymbol{X}_{\mathbf{2}}$ & ditangani & Dinkes \\
$\boldsymbol{X}_{\mathbf{3}}$ & Persentase Bayi Lahir berat badan rendah & Dinkes \\
$\boldsymbol{X}_{\mathbf{4}}$ & Presentase penduduk miskin & BPS \\
$\boldsymbol{X}_{\mathbf{5}}$ & Persentase perempuan kawin dibawah 17 & BPS \\
\hline
\end{tabular}




\section{Langkah Analisis}

Langkah analisis yang digunakan adalah sebagai berikut.

1. Menentukan Faktor- Faktor yang berpengaruh terhadap Angka Kematian Bayi (AKB) dan Angka Kematian Ibu (AKI) di Provinsi Jawa Timur dengan model BGR sebagai berikut:

a. Membuat analisis deskriptif tentang faktorfaktor yang mempengaruhi AKB dan AKI di Provinsi Jawa Timur Tahun 2017 dan tahun 2018.

b. Melakukan pengujian distribusi gamma pada variabel respon AKB dan AKI tahun 2017 dan tahun 2018.

c. Menguji keeratan hubungan antar variabel respon $\mathrm{AKB}$ dan $\mathrm{AKI}$ menggunakan uji korelasi.

d. Melakukan pemeriksaan multikolinearitas antar variabel independen/prediktor dengan nilai VIF.

e. Menganalisis data menggunakan model Bivariate Gamma Regression Regression (BGR) untuk mendapatkan model AKB dan AKI di Provinsi Jawa Timur tahun 2017 dan tahun 2018.

2. Melakukan penaksiran parameter model BGR tahun 2017 dan tahun 2018.

3. Melakukan pengujian model BGR tahun 2017 dan tahun 2018.

4. Menguji kesamaan model BGR tahun 2018 dengan model BGR tahun 2017, dengan langkah sebagai berikut.

a. Menentukan $G_{1}{ }^{2}=-2\left(\ln L\left(\widehat{\omega_{1}}\right)-\ln L\left(\widehat{\Omega_{1}}\right)\right)$. $L\left(\widehat{\omega_{1}}\right)$ merupakan fungsi likelihood untuk model BGR tahun 2018 dibawah $\mathrm{H}_{0}, L\left(\widehat{\Omega_{1}}\right)$ merupakan fungsi likelihood untuk model BGR tahun 2018 dibawah populasi.

b. Menentukan $G_{2}{ }^{2}=-2\left(\ln L\left(\widehat{\omega_{2}}\right)-\ln L\left(\widehat{\Omega_{2}}\right)\right)$. $L\left(\widehat{\omega_{2}}\right)$ merupakan fungsi likelihood untuk model BGR tahun 2017 dibawah $\mathrm{H}_{0}, L\left(\widehat{\Omega_{2}}\right)$ merupakan fungsi likelihood untuk model BGR tahun 2017 dibawah populasi.

c. Menentukan nilai statistik uji $F_{\text {hitung }}=\frac{G_{1}^{2} / d f_{1}}{G_{2}^{2} / d f_{2}}$.

d. Membuat kesimpulan.

5. Menarik kesimpulan dan saran.

IV. ANALISIS DAN PEMBAHASAN

Berikut merupakan analisis pembahasan mengenai pemodelan faktor-faktor yang diduga mempengaruhi angka kematian bayi dan angka kematian ibu di Jawa Timur Tahun 2017 dan 2018.

\section{A. Statistika Deskriptif}

Variabel respon yang digunakan dalam penelitian ini adalah angka kematian bayi (Y1) dan angka kematian ibu (Y2). Berikut ini disajikan Tabel 2 yang berisi gambaran secara deskriptif variabel penelitian tahun 2017 dan tahun 2018.
TABEL 2.

STATISTIKA DESKRIPTIF VARIABEL RESPON

\begin{tabular}{cccccc}
\hline Variabel & Tahun & Mean & Varians & Minimum & Maksimum \\
\hline \multirow{2}{*}{ AKB } & $\mathbf{2 0 1 7}$ & 8,08 & 17,05 & 1,65 & 23,62 \\
& $\mathbf{2 0 1 8}$ & 7,86 & 11,71 & 2,19 & 16,99 \\
\hline \multirow{2}{*}{ AKI } & $\mathbf{2 0 1 7}$ & 97,75 & 1024,59 & 46,48 & 171,88 \\
& $\mathbf{2 0 1 8}$ & 101,00 & 2639,85 & 44,25 & 301,75 \\
\hline
\end{tabular}

Tabel 2 menunjukkan bahwa rata-rata Angka Kematian Bayi ( $\mathrm{Y}_{1}$ ) tahun 2017 dan 2018 masing-masing sebesar 8,08 (sekitar 8 bayi meninggal tiap 1000 kelahiran hidup di Jawa Timur tahun 2017) dan 7,86 (sekitar 7 sampai 8 bayi meninggal tiap 1000 kelahiran hidup di Jawa Timur tahun 2018), dengan varians sebesar 17,05 pada tahun 2017 dan sebesar 11,71 pada tahun 2018, hal tersebut menunjukkan keragaman angka kematian bayi antar kabupaten/kota di Jawa Timur pada tahun 2017 dan 2018 cukup beragam. Rata-rata Angka Kematian Ibu ( $\left.\mathrm{Y}_{2}\right)$ di Jawa Timur sebesar 97,75 (sekitar 97 ibu meninggal tiap 100.000 kelahiran hidup di Jawa Timur) pada tahun 2017 dan sebesar 101 (sekitar $101 \mathrm{ibu}$ meninggal tiap 100.000 kelahiran hidup di Jawa Timur) pada tahun 2018, dengan varians sebesar 1.024,59 pada tahun 2017 dan sebesar 2.639,85 pada tahun 2018 .
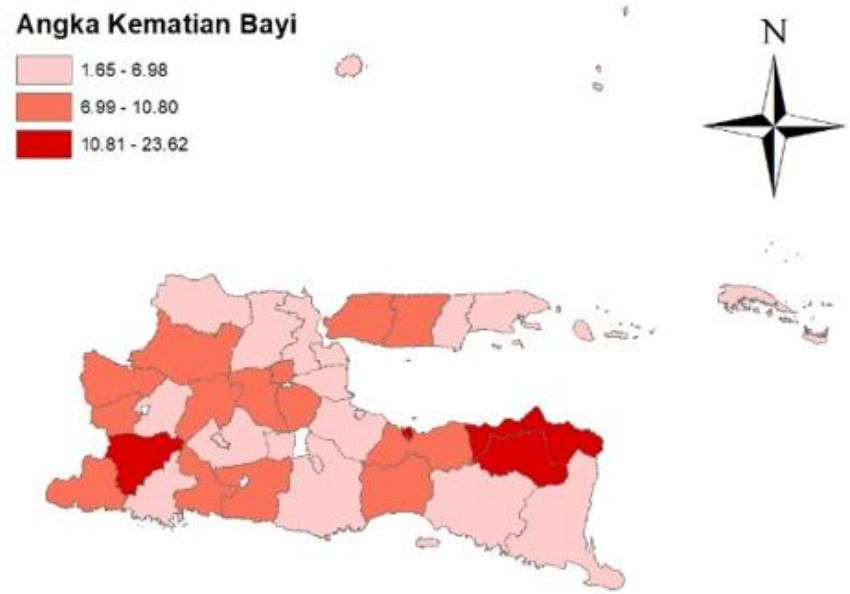

Gambar 2. Persebaran Angka Kematian Bayi di Jawa Timur Tahun 2017
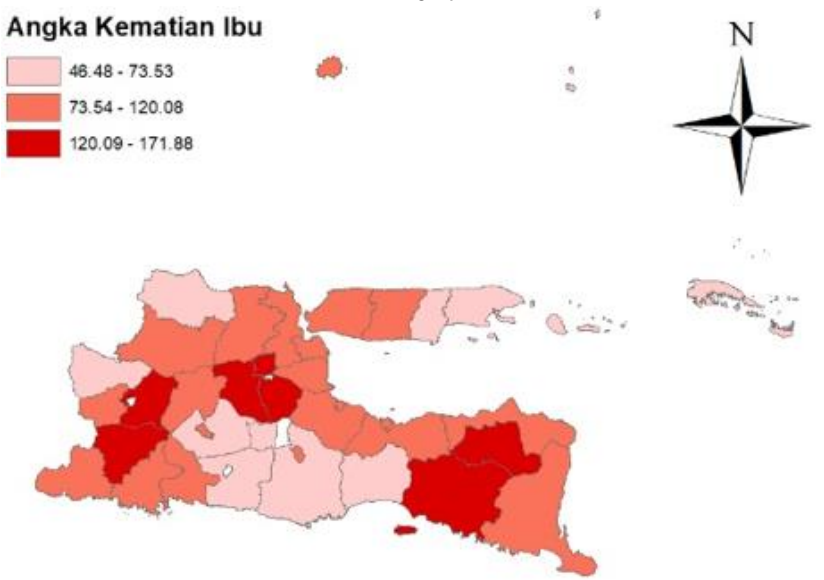

Gambar 3. Persebaran Angka Kematian Ibu di Jawa Timur Tahun 2017

Berdasarkan Gambar 2. persebaran Angka Kematian Bayi di Jawa Timur tahun 2017, terdapat 17 Kabupaten/Kota yang memiliki AKB rendah, 13 Kabupaten/Kota yang memiliki AKB sedang, dan 4 Kabupaten/Kota yang memiliki AKB tinggi. Angka Kematian Bayi terendah terdapat pada 
Kabupaten Malang, sedangkan Angka Kematian Bayi tertinggi terdapat pada Kota Probolinggo. Berdasarkan Gambar 3. persebaran Angka Kematian Ibu di Jawa Timur tahun 2017, terdapat 8 Kabupaten/Kota yang memiliki AKI rendah, 20 Kabupaten/Kota yang memiliki AKI sedang, dan 6 Kabupaten/Kota yang memiliki AKI tinggi. Angka Kematian Ibu terendah terdapat pada Kabupaten Malang, sedangkan Angka Kematian Ibu tertinggi terdapat pada Kabupaten Mojokerto. Peta persebaran AKB dan AKI diatas menujukkan bahwa Kab/Kota yang memiliki AKI tinggi akan memiliki AKB yang tinggi juga.

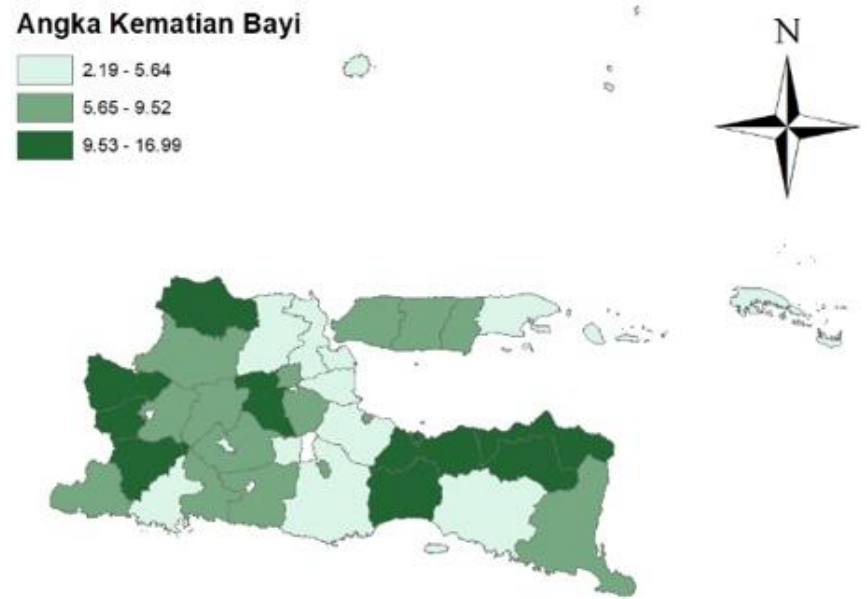

Gambar 4. Persebaran Angka Kematian Bayi di Jawa Timur Tahun 2018
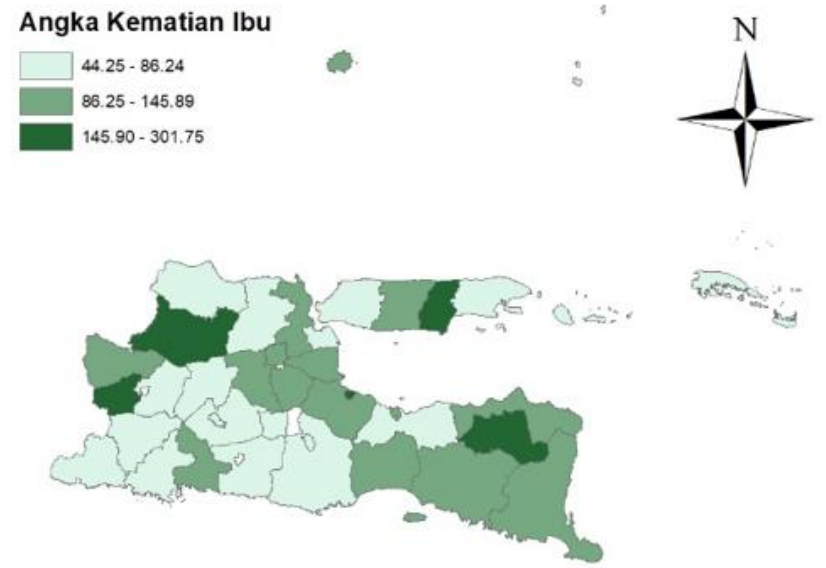

Gambar 5. Persebaran Angka Kematian Ibu di Jawa Timur Tahun 2018

Berdasarkan Gambar 4. persebaran Angka Kematian Ibu di Jawa Timur tahun 2017, terdapat 10 Kabupaten/Kota yang memiliki AKB rendah, 14 Kabupaten/Kota yang memiliki AKB sedang, dan 10 Kabupaten/Kota yang memiliki AKB tinggi. Angka Kematian Bayi terendah terdapat pada Kabupaten Malang, sedangkan Angka Kematian Bayi tertinggi terdapat pada Kabupaten Bondowoso. Berdasarkan Gambar 5. persebaran Angka Kematian Ibu di Jawa Timur tahun 2018, terdapat 12 Kabupaten/Kota yang memiliki AKI rendah, 17 Kabupaten/Kota yang memiliki AKI sedang, dan 5 Kabupaten/Kota yang memiliki AKI tinggi. Angka Kematian Ibu terendah terdapat pada Kabupaten Malang, sedangkan Angka Kematian Ibu tertinggi terdapat pada Kota Pasuruan. Berdasarkan Gambar 4. dan Gambar 5. dapat diketahui bahwa $\mathrm{Kab} /$ Kota yang memiliki AKI tinggi juga memiliki AKB yang tinggi. Berikut ini disajikan hasil statistika deskriptif 5 variabel prediktor.

TABEL 3.

STATISTIKA DESKRIPTIF VARIABEL PENELITIAN

\begin{tabular}{cccccc}
\hline Variabel & Tahun & Mean & Varians & Minimum & Maksimum \\
\hline \multirow{2}{*}{$\mathbf{X}_{\mathbf{1}}$} & $\mathbf{2 0 1 7}$ & 93,97 & 16,82 & 82,40 & 100,00 \\
& $\mathbf{2 0 1 8}$ & 95,52 & 16,97 & 86,50 & 102,30 \\
\hline \multirow{2}{*}{$\mathbf{X}_{\mathbf{2}}$} & $\mathbf{2 0 1 7}$ & 98,84 & 288,04 & 65,24 & 140,58 \\
& $\mathbf{2 0 1 8}$ & 99,00 & 359,55 & 51,46 & 147,89 \\
\hline \multirow{2}{*}{$\mathbf{X}_{\mathbf{3}}$} & $\mathbf{2 0 1 7}$ & 4,14 & 1,94 & 1,10 & 7,70 \\
& $\mathbf{2 0 1 8}$ & 4,13 & 2,23 & 0,80 & 7,70 \\
\hline \multirow{2}{*}{$\mathbf{X}_{\mathbf{4}}$} & $\mathbf{2 0 1 7}$ & 12,32 & 20,07 & 4,17 & 23,56 \\
& $\mathbf{2 0 1 8}$ & 11,52 & 17,78 & 4,10 & 21,21 \\
\hline \multirow{2}{*}{$\mathbf{X}_{\mathbf{5}}$} & $\mathbf{2 0 1 7}$ & 19,09 & 86,05 & 5,21 & 43,59 \\
& $\mathbf{2 0 1 8}$ & 20,78 & 91,26 & 6,52 & 45,05 \\
\hline
\end{tabular}

Berdasarkan Tabel 3 Rata-rata Ibu hamil di Jawa Timur tahun 2017 yang persalinannya dibantu oleh tenaga kesehatan $\left(\mathrm{X}_{1}\right)$ sebesar 93,97 dengan varians sebesar 16,82, sedangkan pada tahun 2018 sebesar 95,52 dengan varians sebesar 16,97. Rata-rata Komplikasi Kebidanan yang ditangani $\left(\mathrm{X}_{2}\right)$ sebesar 98,84 dengan varians sebesar 288,04 pada tahun 2017 sedangkan pada tahun 2018 sebesar 99 dengan varians sebesar 359,55. Hal tersebut menunjukkan bahwa Komplikasi Kebidanan yang ditangani di Jawa Timur dan persentase kasus penanganan tersebut antar kabupaten/kota sangat beragam. Rata-rata bayi lahir berat badan rendah $\left(\mathrm{X}_{3}\right)$ sebesar 4,14 dengan varians sebesar 1,94 pada tahun 2017, sedangkan pada tahun 2018 sebesar 4,13 dengan varians sebesar 2,23. Hal ini berarti persentase kasus bayi lahir dengan berat badan rendah antar kabupaten/kota pada kasus ini cukup beragam. Rata-rata Penduduk miskin $\left(\mathrm{X}_{4}\right)$ sebesar 12,32 dengan varians sebesar 20,07 pada tahun 2017 dan pada tahun 2018 sebesar 11,52 dengan varians sebesar 17,78. Rata-rata perempuan kawin di bawah 17 tahun $\left(\mathrm{X}_{5}\right)$ sebesar 19,09 dengan varians sebesar 86,05 pada tahun 2017 dan sebesar 20,78 dengan varians sebesar 91,26 pada tahun 2018. Hal tersebut menunjukkan bahwa persentase perempuan di Jawa Timur yang berusia 10 tahun ke atas melangsungkan perkawinan pertama sebelum berumur 17 tahun cukup beragam antar kabupaten/kota.

\section{B. Pengujian Distribusi Gamma}

Pengujian distribusi sesuai dengan tinjauan pustaka dilakukan secara univariat. Uji distribusi gamma menggunakan uji Anderson-Darling menghasilkan nilai seperti berikut.

TABEL 4.

UJI DISTRIBUSI GAMMA TAHUN 2017

\begin{tabular}{ccccc}
\hline & \multicolumn{2}{c}{ AKB } & \multicolumn{2}{c}{ AKI } \\
\cline { 2 - 5 } Distribusi & Statistik Uji & $\boldsymbol{P}$-Value & Statistik Uji & $\boldsymbol{P}$-Value \\
\hline Exponensial & 5,091 & 0,003 & 7,362 & 0,003 \\
Weibul & 0,888 & $\mathbf{0 , 0 2 1}$ & 0,444 & $\mathbf{0 , 2 5}$ \\
Gamma & 0,492 & $\mathbf{0 , 2 3 2}$ & 0,194 & $\mathbf{0 , 2 5}$ \\
\hline \multicolumn{3}{c}{ TABEL 5. } \\
\hline & UJI DISTRIBUSI GAMMA TAHUN 2018 \\
\cline { 2 - 5 } Distribusi & Statistik Uji & $\boldsymbol{P}$-Value & Statistik Uji & $\boldsymbol{P}$-Value \\
\hline Exponensial & 5,085 & 0,003 & 5,303 & 0,003 \\
Weibul & 0,174 & $\mathbf{0 , 2 5}$ & 0,945 & $\mathbf{0 , 0 1 6}$ \\
Gamma & 0,209 & $\mathbf{0 , 2 5}$ & 0,44 & $\mathbf{0 , 2 5}$ \\
\hline
\end{tabular}

Berdasarkan Tabel 4 dan Tabel 5. variabel AKB dan AKI di Provinsi Jawa Timur tahun 2017 gagal tolak $\mathrm{H}_{0}$ pada distribusi weibull dan distribusi gamma yang ditunjukkan dengan nilai $p$-value lebih besar dari $\alpha=0,05$. Tetapi nilai $p$ - 
value pada distribusi gamma lebih besar dibandingkan dengan p-value distribusi weibull. Sedangkan untuk distribusi eksponensial menghasilkan keputusan tolak $\mathrm{H}_{0}$, karena nilai p-value kurang dari $\alpha=0,05$. Sehingga variabel AKB dan AKI di Provinsi Jawa Timur tidak mengikuti distribusi eksponensial.

\section{Uji Koefisien Korelasi}

Untuk melihat korelasi antar variabel respon dapat dilihat dari derajat keeratan hubungan antar variabel respon. Nilai korelasi antar variabel respon yang diperoleh sebesar 0,352 pada tahun 2017 dan sebesar 0,303 pada tahun 2018. Pengujian korelasi ditunjukkan pada tabel 6 .

TABEL 6.

PENGUJIAN KOEFISIEN KORELASI

\begin{tabular}{ccc}
\hline Tahun & $\boldsymbol{t}_{\text {hitung }}$ & Keterangan \\
\hline 2017 & $t=\frac{0,32 \sqrt{34-2}}{\sqrt{1-(0,32)^{2}}}=1,911$ & Tolak $\mathrm{H}_{0}$ \\
2018 & $t=\frac{0,39 \sqrt{34-2}}{\sqrt{1-(0,39)^{2}}}=2,396$ & Tolak $\mathrm{H}_{0}$ \\
\hline
\end{tabular}

Berdasarkan Tabel 6 menunjukkan bahwa Nilai thitung yang diperoleh lebih besar jika dibandingkan dengan $t_{(0,05,(2 ; 32))}=$ 1,693, maka $\mathrm{H}_{0}$ ditolak. Kesimpulan yang dihasilkan adalah terdapat hubungan yang signifikan antara Angka Kematian Bayi dengan Angka Kematian Ibu pada tahun 2017 maupun tahun 2018.

\section{Pemeriksaan Multikolinieritas}

Uji multikolinieritas dilakukan untuk menguji hubungan antar variabel prediktor yang diduga mempengaruhi Angka Kematian Bayi dan Angka Kematian Ibu di Jawa Timur tahun 2017 dan 2018. Salah satu cata untuk mendeteksi adanya multikolinieritas dengan menggunakan nilai VIF. Berikut adalah hasil nilai VIF:

TABEL 7. NILAI VIF VARIABEL PREDIKTOR

\begin{tabular}{ccc}
\hline \multirow{2}{*}{ Variabel } & \multicolumn{2}{c}{ VIF } \\
& Tahun 2017 & Tahun 2018 \\
\hline $\mathrm{X}_{1}$ & 1,52 & 1,66 \\
$\mathrm{X}_{2}$ & 1,70 & 1,62 \\
$\mathrm{X}_{3}$ & 3,25 & 2,39 \\
$\mathrm{X}_{4}$ & 1,85 & 1,64 \\
$\mathrm{X}_{5}$ & 4,47 & 4,16 \\
\hline
\end{tabular}

Tabel 6 menunjukan bahwa nilai VIF seluruh variabel prediktor memiliki nilai kurang dari 10 baik pada tahun 2017 maupun tahun 2018, maka dapat disimpulkan bahwa antar variabel prediktor tidak saling berkorelasi, yang berarti tidak terdapat kasus multikolinearitas pada variabel prediktor yang digunakan.

\section{E. Pemodelan Angka Kematian Bayi dan Angka Kematian} Ibu di Jawa Timur Tahun 2017 Menggunakan BGR

Setelah melakukan pemeriksaan asumsi terpenuhi, maka dapat dilanjutkan dengan pemodelan BGR. Pemodelan menggunakan BGR untuk AKB dan AKI di Jawa Timur tahun 2017 diawali dengan estimasi parameter, selanjutnya pengujian secara serentak dan parsial dengan menggunakan $\alpha$ sebesar $5 \%$.
1. Estimasi Parameter Model BGR Tahun 2017

Pemodelan BGR diawali dengan penaksiran parameter, pengujian parameter secara serentak yang kemudian dilanjutkan oleh pengujian parameter secara parsial. Hasil estimasi parameter model Bivariate Gamma Regression AKB dan AKI di Jawa Timur Tahun 2017 di sajikan pada tabel berikut.

TABEL 8.

NILAI ESTIMASI PARAMETER MODEL BGR TAHUN 2017

\begin{tabular}{ccccc}
\hline Parameter & Nilai Estimasi & $\mathbf{S E}$ & $\mathbf{Z}_{\text {hitung }}$ & P-value \\
\hline$\beta_{10}$ & 0,817 & 0,057 & 14,31 & 0,00 \\
$\beta_{11}$ & $-0,015$ & 0,002 & $-7,51$ & 0,00 \\
$\beta_{12}$ & $-0,014$ & 0,002 & $-7,22$ & 0,00 \\
$\beta_{13}$ & 1,069 & 0,041 & 25,98 & 0,00 \\
$\beta_{14}$ & 0,306 & 0,021 & 14,76 & 0,00 \\
$\beta_{15}$ & $-0,194$ & 0,011 & $-18,42$ & 0,00 \\
$\beta_{20}$ & 5,614 & 0,004 & 1459,38 & 0,00 \\
$\beta_{21}$ & $-0,026$ & 0,009 & $-2,81$ & 0,00 \\
$\beta_{22}$ & $-0,023$ & 0,006 & $-3,60$ & 0,00 \\
$\beta_{23}$ & 1,030 & 0,221 & 4,67 & 0,00 \\
$\beta_{24}$ & 0,282 & 0,078 & 3,61 & 0,00 \\
$\beta_{25}$ & $-0,195$ & 0,049 & $-3,99$ & 0,00 \\
\hline
\end{tabular}

Berdasarkan Tabel 8. Diperoleh estimasi parameter model BGR untuk AKB $\left(\hat{\mu}_{1 i}\right)$ dan AKI $\left(\hat{\mu}_{2 i}\right)$ sebagai berikut. $\hat{\mu}_{1 i}=\exp \left(0,817-0,015 x_{1 i}-0,014 x_{2 i}+1,069 x_{3 i}+0,306 x_{4 i}\right.$ $\left.-0,194 x_{5 i}\right)$

$\hat{\mu}_{2 i}=\exp \left(5,614-0,026 x_{1 i}-0,023 x_{2 i}+1,03 x_{3 i}+0,282 x_{4 i}\right.$ $\left.-0,195 x_{5 i}\right)$

Model BGR untuk AKB $\left(\hat{\mu}_{1 i}\right)$ di atas menunjukkan bahwa setiap kenaikan satu persen persalinan oleh tenaga kesehatan, maka akan menurunkan rata-rata angka kematian bayi di Jawa Timur sebesar $\exp (0,015)=0,985$ kali dari rata rata angka kematian bayi semula dengan syarat semua variabel lain konstan. Interpretasi serupa dengan nilai berbeda digunakan untuk variabel persentase komplikasi kebidanan yang ditangani dan variabel perempuan kawin di bawah 17 tahun. Namun terdapat perbedaan dengan teori kesehatan pada variabel persentase bayi lahir berat badan rendah dan persentase penduduk miskin. Setiap kenaikan satu persen kasus bayi lahir berat badan rendah akan meningkatkan ratarata angka kematian bayi sebesar $\exp (1,069)=2,911$ kali dari rata-rata angka kematian bayi dengan syarat semua variabel konstan.

Model BGR untuk AKI $\left(\hat{\mu}_{2 i}\right)$ di atas menunjukkan bahwa setiap kenaikan satu persen persalinan oleh tenaga kesehatan, maka akan menurunkan rata-rata angka kematian ibu di Jawa Timur sebesar $\exp (0,026)=0,975$ kali dari rata rata angka kematian ibu semula dengan syarat semua variabel lain konstan. Interpretasi serupa dengan nilai berbeda digunakan untuk variabel persentase komplikasi kebidanan yang ditangani dan variabel perempuan kawin di bawah 17 tahun. Namun terdapat perbedaan dengan teori kesehatan pada variabel persentase bayi lahir berat badan rendah dan persentase penduduk miskin. Setiap kenaikan satu persen kasus bayi lahir berat badan rendah akan meningkatkan ratarata angka kematian ibu sebesar $\exp (1,03)=2,802$ kali dari rata-rata angka kematian ibu dengan syarat semua variabel konstan. 
2. Pengujian Parameter Model BGR Tahun 2017

Pengujian parameter model BGR dilakukan secara serentak dan parsial. Berdasarkan hasil uji serentak diperoleh nilai $\mathrm{G}^{2}$ sebesar 548,861. Hasil tersebut lebih dari $\chi^{2}$ sehingga dapat disimpulkan $\mathrm{H}_{0}$ ditolak, yang berarti bahwa paling sedikit ada satu variabel prediktor yang berpengaruh terhadap model. Pengujian dilanjutkan menggunakan uji parsial. Hasil pengujian parsial dapat dilihat pada Tabel 8 .

Tabel 8 menunjukkan bahwa variabel persalinan oleh tenaga kesehatan (X1), komplikasi kebidanan yang ditangani (X2), bayi lahir berat badan rendah (X3), penduduk miskin (X4), dan persentase perempuan kawin dibawah 17 tahun (X5) berpengaruh signifikan terhadap model Angka Kematian Bayi dan Angka Kematian Ibu. Hal ini ditunjukkan dengan nilai $p$-value pada variabel tersebut lebih kecil dibandingkan dengan $\alpha=0,05$ atau memiliki $Z_{\text {hitung }}$ lebih besar dari $Z_{\alpha / 2}$

\section{F. Pemodelan Angka Kematian Bayi dan Angka Kematian Ibu di Jawa Timur Tahun 2018 Menggunakan BGR}

Pemodelan menggunakan BGR untuk AKB dan AKI di Jawa Timur tahun 2018 diawali dengan estimasi parameter, selanjutnya pengujian secara serentak dan parsial dengan menggunakan $\alpha$ sebesar $5 \%$.

1. Estimasi Parameter Model BGR Tahun 2018

Pemodelan BGR diawali dengan penaksiran parameter, pengujian parameter secara serentak yang kemudian dilanjutkan oleh pengujian parameter secara parsial. Hasil estimasi parameter model Bivariate Gamma Regression AKB dan AKI di Jawa Timur Tahun 2018 di sajikan pada tabel berikut.

TABEL 9.

\begin{tabular}{ccccc}
\multicolumn{4}{c}{ NILAI ESTIMASI PARAMETER MODEL BGR TAHUN 2018 } \\
\hline Parameter & Nilai Estimasi & SE & Z hitung & P-value \\
\hline$\beta_{10}$ & 2,016 & 0,006 & 355,83 & 0,00 \\
$\beta_{11}$ & $-0,040$ & 0,005 & $-7,42$ & 0,00 \\
$\beta_{12}$ & 0,035 & 0,006 & 5,73 & 0,00 \\
$\beta_{13}$ & 0,364 & 0,077 & 4,70 & 0,00 \\
$\beta_{14}$ & 0,139 & 0,030 & 4,55 & 0,00 \\
$\beta_{15}$ & $-0,113$ & 0,019 & $-5,79$ & 0,00 \\
$\beta_{20}$ & 0,041 & 0,002 & 17,99 & 0,00 \\
$\beta_{21}$ & 0,015 & 0,011 & 1,34 & 0,18 \\
$\beta_{22}$ & 0,067 & 0,015 & 4,55 & 0,00 \\
$\beta_{23}$ & $-0,132$ & 0,202 & $-0,65$ & 0,51 \\
$\beta_{24}$ & 0,139 & 0,057 & 2,44 & 0,01 \\
$\beta_{25}$ & $-0,196$ & 0,039 & $-5,02$ & 0,00 \\
\hline
\end{tabular}

Model yang didapatkan dari hasil penaksiran parameter regresi gamma bivariat untuk AKB $\left(\hat{\mu}_{1 i}\right)$ dan AKI $\left(\hat{\mu}_{2 i}\right)$ yang tersaji pada Tabel 9 dapat diperlihatkan dari persamaan berikut.

$\hat{\mu}_{1 i}=\exp \left(2,016-0,04 x_{1 i}+0,035 x_{2 i}+0,364 x_{3 i}+0,139 x_{4 i}\right.$ $\left.-0,113 x_{5 i}\right)$

$\hat{\mu}_{2 i}=\exp \left(0,041+0,015 x_{1 i}+0,067 x_{2 i}-0,132 x_{3 i}+0,139 x_{4 i}\right.$ $\left.-0,196 x_{5 i}\right)$

Model BGR untuk AKB $\left(\hat{\mu}_{1 i}\right)$ di atas menunjukkan bahwa setiap kenaikan satu persen persalinan oleh tenaga kesehatan, maka akan menurunkan rata-rata angka kematian bayi di Jawa Timur sebesar $\exp (0,04)=0,961$ kali dari rata rata angka kematian bayi semula dengan syarat semua variabel lain konstan. Interpretasi serupa dengan nilai berbeda digunakan untuk variabel perempuan kawin di bawah 17 tahun. Namun terdapat perbedaan dengan teori kesehatan pada variabel persentase komplikasi kebidanan yang ditangani, bayi lahir berat badan rendah dan persentase penduduk miskin. Setiap kenaikan satu persen kasus komplikasi kebidanan yang ditangani akan meningkatkan rata-rata angka kematian bayi sebesar $\exp (0,035)=1,036$ kali dari rata-rata angka kematian bayi dengan syarat semua variabel konstan.

Model BGR untuk AKI $\left(\hat{\mu}_{2 i}\right)$ di atas menunjukkan bahwa setiap kenaikan satu persen persalinan oleh tenaga kesehatan, maka akan meningkatkan rata-rata angka kematian ibu di Jawa Timur sebesar $\exp (0,015)=1,015$ kali dari rata rata angka kematian ibu semula dengan syarat semua variabel lain konstan. Interpretasi serupa dengan nilai berbeda digunakan untuk persentase komplikasi kebidanan yang ditangani dan variabel persentase penduduk miskin. Namun terdapat perbedaan dengan teori kesehatan pada variabel persentase bayi lahir berat badan rendah dan variabel perempuan kawin di bawah 17 tahun. Setiap kenaikan satu persen kasus bayi lahir berat badan rendah akan menurunkan rata-rata angka kematian ibu sebesar $\exp (0,132)=0,877$ kali dari rata-rata angka kematian ibu dengan syarat semua variabel konstan.

\section{Pengujian Parameter Model BGR Tahun 2018}

Pengujian dilakukan seperti pada model BGR tahun 2017, yaitu secara serentak dan parsial. Berdasarkan hasil pengujian serentak diperoleh nilai $\mathrm{G}^{2}$ sebesar 1150,698 . Hasil tersebut lebih dari $\chi^{2}$ sehingga dapat disimpulkan $\mathrm{H}_{0}$ ditolak, yang berarti bahwa paling sedikit ada satu variabel prediktor yang berpengaruh terhadap model. Pengujian dilanjutkan menggunakan uji parsial. Hasil uji parsial ditampilkan pada Tabel 9.

Berdasarkan Tabel 9 menunjukkan bahwa variabel persalinan oleh tenaga kesehatan (X1), komplikasi kebidanan yang ditangani (X2), bayi lahir berat badan rendah (X3), penduduk miskin (X4), dan persentase perempuan kawin dibawah 17 tahun (X5) berpengaruh signifikan terhadap model Angka Kematian Bayi. Hal ini ditunjukkan dengan nilai $p$-value pada variabel tersebut lebih kecil dibandingkan dengan $\alpha=0,05$ atau memiliki $Z_{\text {hitung }}$ lebih besar dari $Z_{\alpha / 2}$, sehingga dapat dijelaskan bahwa, persalinan oleh tenaga kesehatan, komplikasi kebidanan yang ditangani, persentase bayi lahir berat badan rendah, penduduk miskin, dan persentase perempuan kawin dibawah 17 tahun berpengaruh signifikan tehadap Angka Kematian Bayi di provinsi Jawa Timur tahun 2018. Sedangkan Variabel persalinan oleh tenaga kesehatan (X1) dan bayi lahir berat badan rendah (X3) tidak berpengaruh signifikan terhadap Angka Kematian Ibu di Jawa Timur pada Tahun 2018. Namun, berdasarkan hasil pengujian parsial tersebut bukan berarti variabel yang tidak signifikan dalam model tidak berpengaruh terhadap angka kematian ibu di Jawa Timur Tahun 2018. Akan tetapi, secara teori kesehatan dan realita di kehidupan sehari-hari variabel persalinan oleh tenaga kesehatan yang tidak signifikan dalam model berpengaruh terhadap jumlah kematian kematian ibu. Dengan demikian, beberapa faktor yang diduga berpengaruh terhadap angka kematian bayi maupun kematian ibu dalam penelitian ini tetap harus diperhatikan, di mana yang diperhatikan adalah variabel yang signifikan terhadap angka 
kematian bayi dan angka kematian ibu tanpa mengabaikan faktor yang tidak signifikan.

\section{G. Pengujian Kesamaan Kedua Model}

Pengujian kesamaan model ini bertujuan untuk menguji kesamaan faktor-faktor yang mempengaruhi kedua model. Padda uji kesamaan dua model ini, menggunakan semua variabel yang diduga mempengaruhi AKB dan AKI di Jawa Timur. Pengujian kesamaan model ini dilakukan dengan membandingkan nilai likelihood model BGR kesatu dan model BGR yang kedua. Hasil uji kesamaan kedua model ditampilkan pada Tabel 11.

TABEL 10.

UJI KESAMAAN MODEL BGR TAHUN 2017 DAN MODEL 2018

\begin{tabular}{crrrr}
\hline Model & \multicolumn{1}{c}{$\mathbf{G}^{\mathbf{2}}$} & df & $\mathbf{F}_{\text {hitung }}$ & $\mathbf{F}_{\text {tabel }}$ \\
\hline BGR Tahun 2018 & 1557,596 & 10 & & \\
BGR Tahun 2017 & 548,861 & 10 & & 2,322 \\
\hline
\end{tabular}

Berdasarkan Tabel 10 diperoleh informasi bahwa nilai $\mathrm{F}_{\text {hitung }}=2,837$ lebih besar dari nilai $F_{0,1 ; 10,10}$, sehingga keputusannya adalah tolak $\mathrm{H}_{0}$ pada taraf signifikansi $\alpha$ sebesar $10 \%$. Maka dapat disimpulkan bahwa terdapat perbedaan signifikan antara parameter model BGR pada Tahun 2017 dan model BGR pada Tahun 2018. Model BGR pada tahun 2017 dengan model BGR tahun 2018 memiliki karakteristik yang berbeda.

\section{A. Kesimpulan}

\section{KESIMPULAN DAN SARAN}

1. Rata-rata angka kematian bayi di Jawa Timur pada tahun 2017 adalah 8,08 per 1000 kelahiran hidup dengan kematian bayi tertinggi terdapat di Kota Probolinggo yakni sebesar 23,62. Rata-rata angka kematian bayi di Jawa Timur pada tahun 2018 adalah 7,89 per 1000 kelahiran hidup dengan kematian bayi tertinggi terdapat di Kabupaten Bondowoso sebesar 16,99. Sementara rata-rata angka kematian ibu yang terjadi di Jawa Timur tahun 2017 adalah 97,75 per 100.000 kelahiran hidup dengan kematian tertinggi terdapat di Kabupaten Mojokerto yakni sebesar 171,88 kematian ibu per 100.000 kelahiran hidup. Rata-rata angka kematian ibu yang terjadi di Jawa Timur tahun 2018 adalah 101 per 100.000 kelahiran hidup dengan kematian tertinggi terdapat di Kota Pasuruan yakni sebesar 301,75 kematian ibu per 100.000 kelahiran hidup. Kabupaten malang merupakan kabupaten yang memiliki AKB terendah di tahun 2017 dan 2018.

2. Angka Kematian Bayi di provinsi Jawa Timur tahun 2017 dan tahun 2018 dipengaruhi secara signifikan oleh persentase persalinan oleh tenaga kesehatan, persentase komplikasi kebidanan yang ditangani, persentase bayi lahir berat badan rendah, persentase penduduk miskin dan persentase perempuan kawin di bawah 17 tahun.

3. Angka Kematian Ibu di provinsi Jawa Timur tahun 2017 dipengaruhi secara signifikan oleh persentase persalinan oleh tenaga kesehatan, persentase komplikasi kebidanan yang ditangani, persentase bayi lahir berat badan rendah, persentase penduduk miskin dan persentase perempuan kawin di bawah 17 tahun. Sedangkan pada tahun 2018 dipengaruhi signifikan oleh variabel komplikasi kebidanan yang ditangani, persentase penduduk miskin dan persentase perempuan kawin di bawah 17 tahun.

4. Dalam pengujian kesamaan kedua model BGR, diperoleh hasil bahwa terdapat perbedaan signifikan antara model BGR tahun 2017 dan model BGR tahun 2018. Model BGR pada tahun 2017 dengan model BGR tahun 2018 memiiki karakteristik yang berbeda.

B. Saran

Berdasarkan kesimpulan yang diperoleh, dapat dirumuskan saran sebagai berikut.

1. Untuk penelitian selanjutnya disarankan menggunakan distribusi yang lebih sesuai sehingga hasil analisis lebih valid dan dan dalam pengujian distribusi dilakukan secara bivariate.

2. Dapat menambah variabel penelitian atau menggunakan metode yang lain dalam melakukan pemodelan angka kematian bayi maupun ibu agar dapat hasil yang optimal.

3. Bagi Dinas Kesehatan Jawa Timur perlu memprioritaskan dan memberikan arahan kepada masyarakat mengenai kesehatan ibu hamil dengan lebih memperhatikan faktorfaktor yang berpengaruh signifikan terhadap kematian ibu hamil maupun bayi.

\section{DAFTAR PUSTAKA}

[1] Dinkes Provinsi Jawa Timur, "Profil Kesehatan Provinsi Jawa Timur,” Dinkes Jawa Timur, Surabaya, 2018.

[2] R. Walpole, Pengantar Statistika, Jakarta: Gramedia Pustaka Utama, 1993.

[3] T. A. Ewemoje dan O. S. Ewemooje, "Best Distribution and Plotting Positions of Daily Maximum Flood Estimation at Ona River in Ogun-Oshun River Basin," Agricultural Engineering International, pp. 1-13, 2011.

[4] S. Nadarajah dan A. K. Gupta, "Some Bivariate Gamma Distributions," Applied Mathematics Letters 19, pp. 767774, 2006.

[5] D. E. Putri, Purhadi dan D. D. Prastyo, "Parameter estimation and hypothesis testing on geographically weighted gamma regression," The Asian Mathematical Conference 2016, pp. 1-7, 2017.

[6] G. Casella dan R. L. Berge, Statistical Inference, United State of America: Thomson Learning Inc., 2002.

[7] J. R. Budiani, Purhadi dan S. W. Purnami, Penaksiran Parameter dan Statistik Uji Bivariate Gamma Regression, Surabaya: ITS, 2018.

[8] D. N. Gujarati, Basic Econometrics, Fourth penyunt., Gary Burke, 2003.

[9] D. K. Dewi, Purhadi dan Sutikno, "Geographically Weighted Bivariate Gamma Regression in The Analysis of Maternal Mortality Rate and Infant Mortality Rate in North Sumatra Province 2017," IOP Conference Series: Materials Science and Engineering, 2019. 